REMARKS ON THE

NOMENCLATURE AND CONSTITUTION OF CERTAIN

PHARMACEUTIC SUBSTANCES. *

By Thomas Holt, M.D., Univ. Edin.; M.R.C.S. Lond. and Edin., \&c.

THE very same reasons which prompted the London College of Physicians to alter the names of some pharmacopoeial compounds, and to adopt in some instances the supposed chemical nomenclature, might also have suggested to them that new namessesquipedalia verba-should be adopted in other cases for the sake of classical uni. formity! The terms potassa, soda, magnesia, calx, alumina, \&c., do not point to the chemical composition of these substances, but rather leave it to be understood that the same are oxides of the metallic bases, potassium, sodium, \&c. Nor do such terms as cyanogen, ammonia, \&c., give the slightest idea as to how these are composed; who would see in the term cyanogen a bicarburet of nitrogen, or in ammonia a compound of 1 eq. of nitrogen and 3 eq. of hydrogen ultimately, or of 1 eq. of anidogen and 1 eq. of hydrogen proximately?

The names of many of the salts, as argenti nitras, plumbi acetas, \&c., cannot be regarded as literally correct, but are used for their comparative shortness.

Many of the acids, as the nitric $\left(\mathrm{NO}_{5}\right)$, oxalic $\left(\mathrm{C}_{2} \mathrm{O}_{3}\right)$, acetic $\left(\mathrm{C}_{4} \mathrm{H}_{3} \mathrm{O}_{3}\right)$, \&c., have not as yet been isolated, or shown to have any separate existence; and even if they could be so isolated, would be entirely different from their hydrated componnds which are received into the pharmacopoias. Anhydrous sulphuric acid does not appear to be acid at all, "does not redden litmus, and exhibits a disposition to combine with salts, such as chloride of potassium and sulphate of potash, rather than with bases." "The liquid carbonic acid has little affinity for water, does not combine directly with lime, but dissolves in alcohol, æher, and essential oils, like certain neutral bodies." The white precipitate of mercury of the late London and of the present Edinburgh pharmacopœias, was considered by Hennel to consist of

1 eq. red oxide of mercury,

1 eq. hydrochloric acid,

1 eq. ammonia.

Phillips and the London College name it ammonio-chloride of mercury, and consider it as composed of

1 eq. corrosive sublimate,

1 eq. red oxide of mercury,

2 eq. ammonia;

but Dr. Kane proves that it contains no oxygeu, consequently both the above must be erroneous. The view proposed by the latter

* See also page 417. high authority, and in this opinion of its constitution he is supported by Liebig, Graham, Gregory, \&c., is, that it is a compound of the anide with the chloride of mercury. Dr. Christison (Ph. Edinb.) considers it as " chloride of mercury (calomel) with ammo. nia." Another view of its constitution might be taken (which has not been suggested that I am aware of ), viz., to consider it as composed of a compound basyle analogous to ammonium* with chlorine, for it has the composition of the chloride of ammonium, only that two atoms of hydrogen are replaced by two corresponding atoms of mercury ; and Wohler's white precipitate has a similar composition, one atom ouly of hydrogen being replaced by mercury; and, according to Mitscherlich, the crystalline form of the latter belongs to the regular system, like that of sal ammoniac (quoted by Graham). This would rather tend to strengthen the eq. of mercury being 101, which has been doubtful, chemists being ignorant of any unobjectionable isomorphous relation of mercury to the magnesian family: in the above, however, we have mercury substituted for hydrogen (which is of the magnesian class), and the form of the crystal remaining the same. The following formulæ may be given ; viz.

$\mathrm{H} \mathrm{Ad}+\mathrm{H} \mathrm{Cl}=$ Kane's formula for sal ammoniac.

$\mathrm{Hg}_{\mathrm{g}} \mathrm{Ad}+\mathrm{Hg} \mathrm{Cl}=$ ditto white precipitate.

$\mathbf{N H}_{4}+\mathbf{C I}=$ Berzelius's view of sal am. moniac.

$\left(\mathrm{NH}_{2} \mathrm{Hg}_{2}\right)+\mathrm{Cl}=$ view proposed of constitution of ordinary white precipitate.

$\left(\mathrm{NH}_{3} \mathrm{Hg}\right)+\mathrm{Cl}=$ ditto of Wohler's white precipitate.

$\mathrm{Hg} \mathrm{Cl}+\mathrm{NH}_{3}=$ formula of Wohler's white precipitate, given by Graham from analysis of Kane.

The constitution of the ammonio-chloride of copper, which appears analogous to that of the white precipitates, also favours the view proposed if the formula be compared.

$\mathrm{NH}_{3} \mathrm{Cu}+\mathrm{Cl}=$ chloride of cuprammonium (Graham).

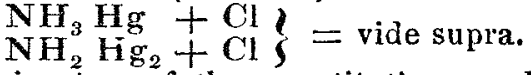

This view of the constitution would apply also to the other precipitates of mercury, formed analogonsly with salts like the chloride. By-the-by, Dr. Pereira, in his work

* In medical practice, whichever view may be adopted of the chemical constitution, the term white precipitate of mercury appears as good as any, and not likely to be generally superseded; but if the view proposed be received chemically, a term composed of bydrargyrum and ammonium-like cuprammonium - would be objectionable from its length, but some such term as Hermammonium, from 'E $\rho \mu \eta s$, Mercury, might be suggested. 
on Materia Medica, is not satisfied with such terms as potassio-tartrate of soda, potassiotartrate of antimony, \&c., but must coin new ones; and gives for the same, sodio-tartrate of potash, antimonio-tartrate of potash, \&c. : thus adding to the confusion (which is already quite enough), without there appearing the slightest necessity, or those he proposes having any greater recommendation than the terms given by the college (if we are to have new ones).

Bury, Lancashire, Aug. 3, 1842.

\section{DR. ADAM SMITH ON MEDICAL DEGREES.}

WE extract the following letter of Adam Smith to Cullen, from the appendix to Maculloch's edition of the "W "Walth of Nations." Cullen had endeavoured through the influence of the Duke of Buccleugh to get a royal commission appointed for the visitation of the Scotch universities, with a view to correcting the abuses in their constitution and discipline, more particularly in the practices of Aberdeen and St. Andrew's in granting degrees. The Duke of Buccleugh requested Cullen to submit his memorial to Dr. Smith for his opinion. This having been done, Smith replied,-

"My dear doctor, -I have been very much in the wrong both to you and to the Duke of Buccleugh, to whom I certainly promised to write you in a post or two, for baving delayed so long to fulfil my promise. The truth is, some occurrences which interested me a good deal, and which happened here immediately after the duke's departure, made me forget altogether a business which I do acknowledge interested me very little.

"In the present state of the Scotch universities, I do most sincerely look upon them as, in spite of all their faults, without exception the best seminaries of learning that are to be found any where in Europe. They are, perhaps, upon the whole, as unexceptionable as any public institutions of that kind, which all contain in their very nature the seeds and causes of negligences and corruption, have ever been, or are ever likely to be. That, however, they are still capable of amendment, and even of considerable amendment, I know very well, and a visitation is, I believe, the only proper means of procuring them this amendment. Before any wise man, however, would apply for the appointment of so arbitrary a tribunal, in order to improve what is already, upon the whole, very well, he ought certainly to know with some degree of certainty, first, who are likely to be appointed visitors ; and, secondly, what plan of reformation those visitors are likely

No. 990. to follow. But in the present multiplicity of pretenders to some share in the provincial management of Scotch atfairs, these are two points which $I$ apprehend neither you nor I, nor the solicitor-general, nor the Duke of Buccleugh, can possibly know anything about. In the present state of our affairs, therefore, to apply for a visitation in order to remedy an abuse, which is not perhaps of great consequence to the public, would appear to me to be extremely unwise. Hereafter, perhaps, an opportunity may present itself for making such an application with more safety.

"With regard to any admonition or threatening, or any other method of interfering in the affairs of a body corporate, which is not perfectly and strictly regular and legal, these are expedients which $I$ am convinced neither his majesty nor any of his present ministers would choose to employ esther now or at any time hereafter, in order to obtain an object even of much greater consequence than this reformation of Scotch degrees.

"You propose, I observe, that no person should be admitted to examination for his degrees, unless he brought a certificate of his having studied at least two years in some university. Would not such a regulation be oppressive upon all private teachers, such as the Hunters, Hewson, Fordyce, \&c.? The scholars of such teachers surely merit whatever honour or advantage a degree can confer, much more than the greater part of those who have spent many years in some unirersities, where the different branches of medical knowledge are either not taught at all, or taught so superficially that they had as well not be taught at all. When a man has learned his lesson very well, it surely can be of little importance where or from whom he has learnt it.

"The monopoly of medical education which this regulation would establish in favour of universities would, I apprehend, be hurtful to the lasting prosperity of such bodies corporate. Monopolists very seldom make good work, and a lecture which a certain number of students must attend, whether they profit by it or no, is certainly not very likely to be a good one. I have thought a great deal upon this subject, and have inquired very carefully into the constitution and history of several of the principal universities of $\mathbf{E u}$ rope. I have satisfied myself, that the present state of degradation and contempt into which the greater part of those societies have fallen in almost every part of Europe, arises principally, first, from the large salaries which in some universities are given to professors, and which render them altogether independent of their diligence and success in their professions; and, secondly, from the great number of students who, in order to get degrees, or to be admitted to exercise certain professions, or who, for the sake of bursaries, exhibitions, scholarships, fellowships,

$2 \mathrm{Z}$ 